\title{
Effect of salinity on growth and nutrient uptake of Ulva pertusa (Chlorophyta) from an eelgrass bed
}

\author{
Tae Seob Choi ${ }^{1, a}$, Eun Ju Kang ${ }^{1}$, Ju-hyoung Kim ${ }^{1}$ and Kwang Young Kim ${ }^{1, *}$ \\ ${ }^{1}$ Department of Oceanography, Chonnam National University, Gwangju, 500-757, Korea
}

Received 15 July 2009, Accepted 28 November 2009

The effects of salinity on various ecophysiological parameters of Ulva pertusa such as growth, nutrient uptake, photosynthetic performance and internal nutrient composition were tested. $U$. pertusa was collected from an eelgrass bed in a semi-protected embayment on the southwest coast of Korea. Under salinity regimes from 5 to 40 psu, the specific growth rates $(\mu)$ of $U$. pertusa ranged from 0.019 to $0.032 \mathrm{~d}^{-1}$. Maximum growth rate was observed at 20 psu, and minimum at $40 \mathrm{psu}$. This species showed various uptake rates for nitrate and phosphate. Nutrient uptake was noticeably higher at intermediate salinity levels, and lower at both extremes. Salinity significantly influenced chlorophyll- $a$ content and effective quantum yield. Tissue nitrogen content ranged from 1.5 to $2.9 \% \mathrm{~N}$ (dry weight), whereas tissue phosphorus ranged from 0.1 to $0.14 \% \mathrm{P}$ (dry weight). The $\mathrm{N}: \mathrm{P}$ ratio in the tissue of $U$. pertusa was considerably higher, ranging from 30 to 50 . Increased growth at lower salinity suggests that the initial growth rate of $U$. pertusa is greater during the rainy season (i.e., late spring and early summer) than any other season during the year. The appearance of an Ulva bloom in eelgrass beds may be triggered by salinity more than by other environmental factors such as light and temperature.

Key Words: eelgrass bed; growth rate; nitrate; nutrient uptake; phosphate; salinity; Ulva pertusa

\section{INTRODUCTION}

Mass growth of macroalgae in shallow coastal waters is one of the most conspicuous results of eutrophication (Valiela et al. 1997, Nelson et al. 2008). Seagrass decline caused by green macroalgal blooms occurs throughout the world. These extensive mats formed by ephemeral green macroalgae such as Ulva, Enteromorpha and Cladophora present a serious management problem in shallow estuaries and coastal areas in many geographical locations, including the southern coast of Korea (Lavery et al. 1991, Schramm and Nienhuis 1996, Choi et al. 2001, Nelson et al. 2008, Liu et al. 2009). In temperate regions, the growth of mat forming algae occurs mainly in the early spring and may persist at high densities throughout the summer before disappearing in the late autumn (Hull 1987, Sfriso et al. 1992, Valiela et al. 1997, Kinney and Roman 1998, Choi et al. 2001, Kim et al. 2004, Liu et al. 2009). Macroalgal blooms can decrease biodiversity, and change community structure and biogeochemical cycles (Rivers and Peckol 1995). Finally, macroalgal blooms can lead to undesirable ecological changes (Isaksson and Phil 1992, Short et al. 1995). Such structural changes in the macroalgal community can

\footnotetext{
*Corresponding author

E-mail: kykim@chonnam.ac.kr

Tel: +82-62-530-3465, Fax: +82-62-530-0065

${ }^{a}$ Present address: Neo Environmental Business Co. \#A-1306, Bucheon Daewoo TechnoPark, Dodang dong 187-7 Wonmi-gu, Bucheon, Gyeonggi-do, 420-806, Korea
} 
influence carbon and nitrogen fluxes, negatively impact fauna in the underlying sediment, and affect predators of benthic fauna (Hemminga and Duarte 2000).

The principal negative effect of Ulva blooms in seagrass beds is the disappearance of many patches (McGlathery 2001). This is due primarily to a decrease in light (Hemminga and Duarte 2000). Light interception by Ulva growing in seagrass beds results in a decrease of the depth limit and cover of seagrasses (KrauseJensen et al. 2000, Hauxwell et al. 2001). Another consideration is the high rate of decay of macroalgal biomass, which results in oxygen depletion in the water column and the release of $\mathrm{H}_{2} \mathrm{~S}$ from macroalgal mass into the surrounding ecosystem (Nedergaard et al. 2002). Finally, the temporary disappearance of benthos and fish populations due to local anoxic conditions may lower species diversity (Hemminga and Duarte 2000). On the other hand, a positive effect of Ulva dominance on seagrass beds is the removal of excess nutrients in the water column, thus preventing the overgrowth of phytoplankton (Burkholder et al. 2007). Intertidal seaweeds periodically exposed to air experience a variety of environmental stresses, including nutrient limitation, high light, extremely high and low temperatures, desiccation, and especially salinity (osmotic stress) (Davison and Pearson 1996). Similarly, there are many environmental factors which affect growth and nutrient uptake of Ulva. Among those factors, salinity is thought to be the most important. It is widely known that lowered salinity negatively affects growth and nutrient uptake of macroalgae such as the genus Ulva (Fong et al. 1996, Martins et al. 2001). Salinity can also affect ionic concentration, the density of seawater, and especially its osmotic pressure (Lobban and Harrison 1994). The most important biological effects of salinity are the osmotic consequence of the movement of water molecules along water-potential gradients, and the flow of ions along electrochemical gradients. These processes take place simultaneously, and both are regulated in part by semipermeable membranes (Lobban and Harrison 1994). Dickson et al. (1982) studied the responses of $U$. lactuca to salinity fluctuations and concluded that changes in internal solute concentrations closely follow salinity fluctuations, reducing the changes in turgor pressure. Ulva and Enteromorpha are both euryhaline. They are protected from salinity stress by a flexible thin cell membrane which allows cells to swell with the influx of water in low salinities (Young et al. 1987a, $1987 b)$. Although there is an increase in inorganic ions, sucrose and proline, cell volume decreases under the higher salinities (Edward et al. 1987). Also, Ulva and Enteromorpha can be repeatedly plasmolyzed and deplasmolyzed without injury to the membranes (Ritchie and Larkum 1987). Increased and decreased salinity result in stress to macroalgae. Thus, it is possible that salt tolerant macroalgae have different strategies for growth and nutrient uptake.

Due to the complex interaction of green-tide forming macroalgae and surrounding environments such as sediment characteristics, composition of plant and fauna, and nutrient cycles within the seagrass beds, it is important to understand which variables control macroalgal abundance and regulate the initiation of macroalgal blooms. The objective of this study was to identify 1) the salinity effect on growth, nutrient uptake and internal nutrient content of $U$. pertusa, and 2) which factors are responsible for variations in ecophysiological parameters of $U$. pertusa growing in an eelgrass bed on subtidal mudflats.

\section{MATERIALS AND METHODS}

\section{Sample preparation}

Thalli of Ulva pertusa Kjellman (hereafter Ulva) were collected from a subtidal mudflat in and around an eelgrass bed (Zostera marina L.) in Haenam $\left(34^{\circ} 18^{\prime}\right.$ $\mathrm{N}, 126^{\circ} 33^{\prime} \mathrm{E}$ ), on the southwest coast of Korea. This region has a relatively pristine eelgrass population with scattered patches of Ulva representing $80-100 \%$ cover. Water chemistry adjacent to the eelgrass bed indicated that the waters were oligotrophic, with ammonium + nitrate and phosphate concentrations from October 2001 to March 2002 ranging from 2.40-6.73 $\mu \mathrm{M}$ and 0.29$1.91 \mu \mathrm{M}$, respectively (Table 1). These environmental conditions, including the mud bottom and low nutrient concentration, are unfavorable for Ulva. Environmental parameters were measured in the eelgrass bed from October 2001 to March 2002 (Table 1) and fresh plant material was collected two days prior to laboratory experiments in March 2002. Thalli were protected from direct sunlight and heating during transportation to the laboratory, where they were kept in a constant

Table 1. Physico-chemical parameters recorded for six months (October 2001 to March 2002) prior to sample collection in eelgrass beds at Haenam, southwestern coast of Korea

\begin{tabular}{ll}
\hline Environmental parameter & Range $($ mean $\pm \mathrm{SD})$ \\
\hline Temperature $\left({ }^{\circ} \mathrm{C}\right)$ & \\
$\quad$ Seawater & $6.7-21.6(11.6 \pm 4.4)$ \\
$\quad$ Air & $2.1-16.3(6.1 \pm 5.7)$ \\
Salinity (psu) & $30.5-32.8(30.6 \pm 1.4)$ \\
Nitrate + Ammonium $(\mu \mathrm{M})$ & $2.40-6.73(4.52 \pm 1.53)$ \\
Phosphate $(\mu \mathrm{M})$ & $0.29-1.91(1.07 \pm 0.55)$ \\
\hline
\end{tabular}


temperature room at $15^{\circ} \mathrm{C}$. Whole thalli were washed with $0.2 \mu \mathrm{m}$ filtered seawater and cleaned to remove surface contaminants.

Sample disks for growth and nutrient uptake measurements were obtained by cutting the adult thalli with a $22 \mathrm{~mm}$ cork borer and allowing samples to recover from wound-induced respiration. Fresh Ulva has a diffuse pattern of growth, so samples were randomly cut from each thallus. Samples were assessed after collection for photosynthetic yield with a DivingPAM (Waltz, Effeltrich, Germany), and tissue samples were analyzed for chlorophyll- $a$, nitrogen $(\mathrm{N})$ and phosphorus (P) levels. Before growth and nutrient uptake were measured, disks were incubated for two days in water from the sampling site to allow adaptation to laboratory conditions. Samples were maintained in a low concentration medium (below $1.34 \mu \mathrm{M}$ of nitrate and $0.64 \mu \mathrm{M}$ of phosphate) and were allowed to adapt over three days. At the beginning of the experiment, a nutrient solution ( $30 \mu \mathrm{M}-\mathrm{N}$ and $8 \mu \mathrm{M}-\mathrm{P})$ was added to the culture vessel. After waiting $12 \mathrm{~h}$ to establish chemical equilibrium, thallus disks were put into the vessel. This condition was confirmed as optimal in a preliminary study, such that the $\mathrm{N}: \mathrm{P}$ atomic ratio of this condition is approximately 4.67 .

\section{Experimental design}

Ulva was exposed to six different salinities, 5, 15, $20,25,34$ and 40 psu with enriched nitrogen and phosphorus for 7-day periods. Each treatment consisted of three replicates, each containing fifteen disks of Ulva in $300 \mathrm{~mL}$ freshly collected, $0.2 \mu \mathrm{m}$ filtered seawater (34 psu) with designated nutrient added from stock solutions. Salinities lower than natural seawater (34 psu) were obtained by diluting the filtered seawater with deionized (demineralized) water. For the higher salinities, natural seawater was concentrated to the desired level by adding artificial sea salt $(\mathrm{NaCl})$. Salinity was checked using a refractometer (S/Mill-E; Atago, Japan). All aquaria were gently aerated to ensure water movement and gas equilibrium. All experiments were performed at $15^{\circ} \mathrm{C}, 200 \mu \mathrm{mol}$ photons $\mathrm{m}^{-2} \mathrm{~s}^{-1}$ in a $16 \mathrm{~h}$ light : $8 \mathrm{~h}$ dark cycle. Light was provided by cool-white fluorescent tubes $(40 \mathrm{~W})$ and metal halide lamps (HQI 150W ; Osram, Berlin, Germany) and monitored with an LI-190SA flat quantum sensor (LI-Cor, Lincoln, NE, USA).

\section{Growth, nutrient uptake, chlorophyll-a and tissue nutrient analyses}

Growth rates under various salinity conditions were measured every 2-3 days for the 7-day experimental period. The disk area was determined using a ruler and replaced in the new medium aquaria for avoiding from depletion of nutrient. Before changing new medium aquaria, water samples were collected to determine changes on nitrate and phosphate concentrations were collected. The specific growth rate $(\mu)$ was calculated using the equation: $\mu=\ln \left(L_{\mathrm{t}} / L_{\mathrm{o}}\right) /\left(t_{2}-t_{1}\right)$, where $t$ is the time in days, $L_{\mathrm{o}}$ is the initial area and $L_{\mathrm{t}}$ is the area on day $t$. Nutrient uptake was calculated from concentrations between sampling intervals, as $\mu \mathrm{M} g$ FW $\mathrm{h}^{-1}$. Chlorophyll- $a$ content was spectrophotometrically determined after extraction using $4 \mathrm{~mL}$ DMF (dimetylformamide), and calculated using the Jeffrey and Humphrey (1975) formula.

Inorganic nitrogen $\left(\mathrm{NO}_{3}{ }^{-} \mathrm{N}\right)$ and reactive phosphorus $\left(\mathrm{PO}_{4}{ }^{3-}-\mathrm{P}\right)$ levels were determined using standard colorimetric methods described in Grasshoff et al. (1983). Disk samples were dried at $60^{\circ} \mathrm{C}$ to a constant dry weight and then ground in a mill (Fritsch, Analysette, Idar-Oberstein, Germany) in order to determine levels of primary elements ( $\mathrm{C}, \mathrm{N}$ and $\mathrm{P}$ ). The carbon and nitrogen contents of powdered plant tissue were measured with an elemental analyzer (EA1110CHNS-O; CE Instruments, Milan, Italy). Phosphorus content was measured using alkaline persulfate digestion (D'Elia et al. 1977) followed by a standard colorimetric phosphate determination of the digested solution (Grasshoff et al. 1983).

\section{Chlorophyll fluorescence measurements}

In vivo induced chlorophyll $a$ fluorescence was determined with a portable pulse amplitude modulated fluorometer (Diving-PAM; Waltz, Effeltrich, Germany). Effective quantum yield $\left(\Delta F / F_{\mathrm{m}}{ }^{\prime}\right)$ of photosystem II were calculated as $\left(F_{\mathrm{m}}{ }^{\prime}-F\right) / F_{\mathrm{m}}{ }^{\prime}$, where $F$ is fluorescence yield of the light-adapted sample and $F_{\mathrm{m}}$ ' is the maximum lightadapted fluorescence yield when a saturating light pulse of 800 ms duration (intensity $\approx 3,000 \mu \mathrm{mol}$ photons $\mathrm{m}^{-2}$ $\mathrm{s}^{-1}$ ) is superimposed on the prevailing environmental light levels (Schreiber and Bilger 1993).

\section{Statistical analysis}

A one-way ANOVA was used to examine the impact of salinity on growth rate, nutrient uptake and concentration of internal elements in the tissue of Ulva. If a factor was significant, then Tukey's test was applied to compare multiple means. The significance level used was $\mathrm{p}<0.05$. The computer package software SYSTAT (Version 4.0 ; Systat Inc., Evanston, IL, USA) was used for all analyses. 


\section{RESULTS}

\section{Growth responses}

Specific growth rates $(\mu)$ of Ulva varied between 0.019 and $0.032 \mathrm{~d}^{-1}$ and were significantly affected by salinity levels ( $<<0.001$ ) (Table 2). Growth rates of Ulva followed a bell-shaped curve (Fig. 1), characterized by higher growth at intermediate levels of salinity (15-34 psu) and lower growth at extreme low and high salinity $(<15$ and $>34 \mathrm{psu}$ ). In both extremes, the samples showed little growth, occasional cell sloughing was observed and some thalli became wrinkled when grown at salinities of 34 psu and higher. Multiple comparisons revealed that the growth rates of Ulva at 15, 20, 25 and 34 psu were significantly greater than those at 5 and 40 psu (Tukey tests, $\mathrm{p}<0.01$ ) (Fig. 1).

Table 2. Summary of the analysis of variance (one-way fixed ANOVA) for the effects of salinity on various factors including growth rate, chlorophyll- $a$, nutrient uptake and tissue nutrient content in $U$. pertusa from eelgrass beds at Haenam $(n=6)$

\begin{tabular}{lrl}
\hline Source of variance & F- statistic & p-value \\
\hline Growth rate & 13.298 & 0.000 \\
Nitrate uptake & 6.785 & 0.000 \\
Phosphate uptake & 5.325 & 0.001 \\
Chlorophyll- $a$ & 5.261 & 0.009 \\
Quantum yield & 30.593 & 0.000 \\
Carbon content & 4.452 & 0.016 \\
Nitrogen content & 10.873 & 0.000 \\
Phosphorus content & 5.021 & 0.010 \\
\hline
\end{tabular}

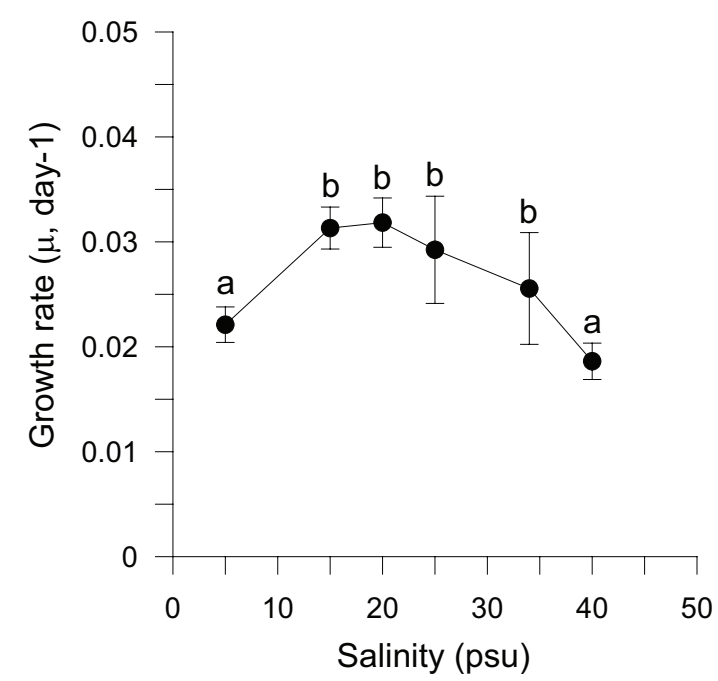

Fig. 1. Specific growth rates $\left(\mu, d^{-1}\right)$ of Ulva pertusa from eelgrass beds as a function of salinity. Error bars represent the mean $( \pm S D)$ of 3 replicates. Letters represent the results of multiple comparison test ( $p$ $<0.05)$.

\section{Nutrient uptake}

Nutrient uptake by Ulva showed a similar pattern for both nitrate and phosphate (Fig. 2). The highest rate of nitrate uptake occurred at 20 psu (Fig. 2A), while the highest rate of phosphate uptake was at 25 psu (Fig. 2B). Nutrient uptake was higher with intermediate salinities, and lower at both extremes. The highest nitrate uptake rate $\left(\mu \mathrm{M} \mathrm{g}^{-1} \mathrm{FW} \mathrm{h}^{-1}\right)$ observed was $0.984 \mu \mathrm{M} \mathrm{g}^{-1} \mathrm{FW} \mathrm{h}^{-1}$ at $20 \mathrm{psu}$, and the lowest $0.683 \mu \mathrm{M} \mathrm{g}^{-1} \mathrm{FW} \mathrm{h}^{-1}$ at $15 \mathrm{psu}$. As for phosphate, the highest uptake rate was $0.157 \mu \mathrm{M} \mathrm{g}^{-1}$ $\mathrm{FW} \mathrm{h}^{-1}$ at $25 \mathrm{psu}$ and the lowest was $0.040 \mu \mathrm{M} \mathrm{g}^{-1} \mathrm{FW} \mathrm{h}^{-1}$ at 15 psu. Maximum nitrate uptake was on average up to six times higher than for phosphate. The difference between maximum and minimum nitrate uptake was $150 \%$, while that for phosphate was $400 \%$. From this, it appears that salinity has a greater impact on phosphate
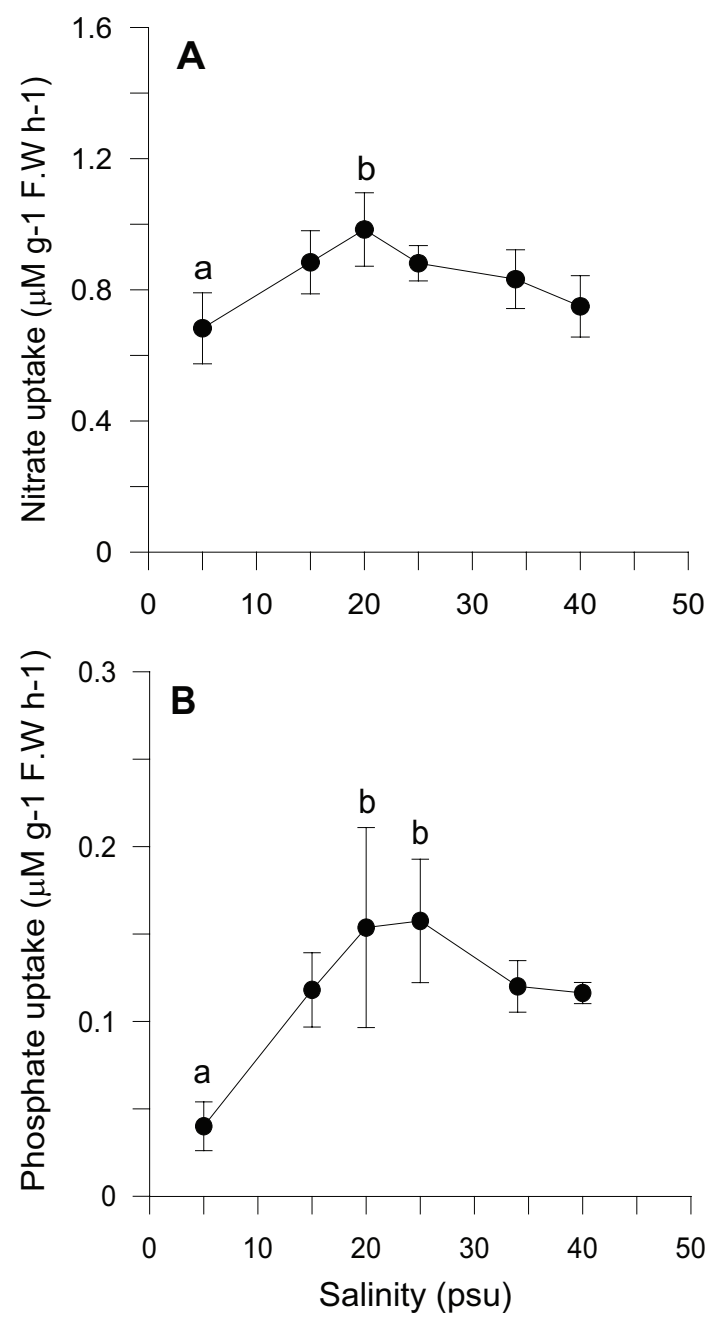

Fig. 2. Uptake rates $\left(\mu \mathrm{M} \mathrm{g}^{-1} \mathrm{FW} \mathrm{h}^{-1}\right)$ of nitrate $(\mathrm{A})$ and phosphate $(\mathrm{B})$ for Ulva pertusa as a function of salinity. Error bars represent the mean $( \pm S D)$ of 3 replicates. Letters represent the results of multiple comparison test $(p<0.05)$. 
uptake than on nitrate uptake. There was a significant difference in the effect of salinity on the uptake of both nutrients, based on the results of a one-way ANOVA test $(\mathrm{p}<0.001)$ (Table 2). Nitrate uptake was significantly different between 5 and 20 psu treatments (Tukey tests, p < 0.01) (Fig. 2A), while phosphate uptake at 20 and 25 psu was significantly different from 5 psu (Tukey tests, $p$ $<0.01$ ) (Fig. 2B).

\section{Chlorophyll- $a$ content and photosynthetic quantum yield}

Chlorophyll- $a$ content and effective quantum yield of Ulva in our experimental treatment had a similar pattern to growth rate (Fig. 3). Over the range of salinity, the mean chlorophyll- $a$ content was $2.31 \pm 0.85 \mu \mathrm{g} \mathrm{cm}{ }^{-2}$. Chlorophyll- $a$ content varied between 1.10 and 2.96
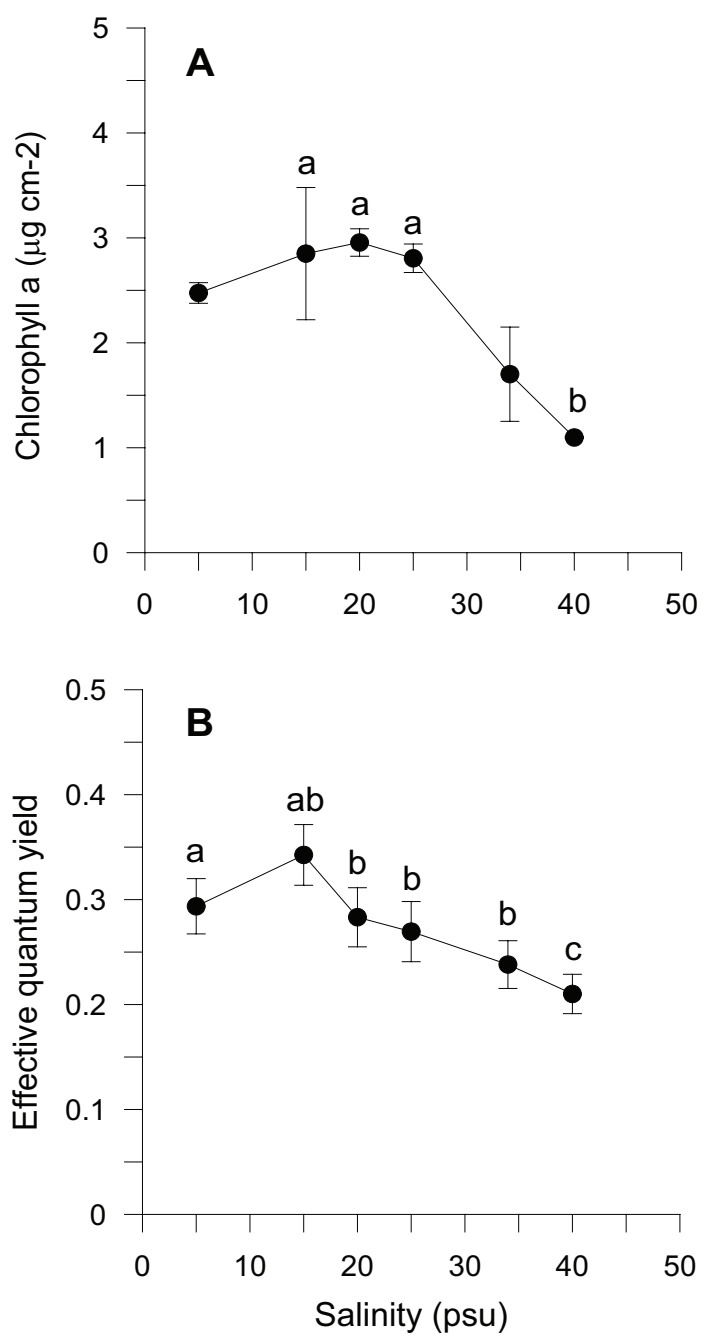

Fig. 3. Chlorophyll-a concentrations $\left(\mu \mathrm{g} \mathrm{cm}^{-2}\right)(A)$ and effective quantum yield (B) of Ulva pertusa determining after experiment end as a function of salinity. Error bars represent the mean ( \pm SD) of 3 or 5 replicates. Letters represent the results of multiple comparison test ( $p$ $<0.05)$. $\mu \mathrm{cm}^{-2}$ with changing salinity levels (Fig. 3A). Effective quantum yield $\left(\Delta F / F_{\mathrm{m}}{ }^{\prime}\right)$ ranged from 0.21 to 0.34 (Fig. 3B). The highest content of chlorophyll- $a$ was observed at the highest growth rate, $20 \mathrm{psu}$, while effective quantum yield was highest at 15 psu. Chlorophyll- $a$ contents were less at higher salinities. Effective quantum yield was also less at higher salinities. Effective quantum yield suggested that Ulva samples grown in lower salinity were photosynthetically active. There was a sharp drop at higher salinities ( $>25 \mathrm{psu}$ ) in chlorophyll- $a$ content, also a sharp decrease with higher salinities (> $15 \mathrm{psu})$ in the effective quantum yield.

Salinity levels significantly affected both chlorophyll- $a$ and effective quantum yield $(\mathrm{p}<0.01$ and $\mathrm{p}<0.001)$, respectively (Table 2). Multiple comparisons among salinity levels showed that chlorophyll- $a$ content at 15,20 and 25 psu were significantly more than those at 40 psu (Tukey tests, $\mathrm{p}<0.05$ ) (Fig. 3A). Tukey test demonstrated that effective quantum yields at 15, 20, 25 and 34 psu were significantly greater than 40 psu (Tukey tests, $\mathrm{p}<0.001$ ), while 5 psu was significantly different to 20, 25, 34 and 40 psu (Tukey tests, $\mathrm{p}<0.001$ ) (Fig. 3B).

\section{Tissue carbon, nitrogen and phosphorus}

Tissue nitrogen content ranged from 1.6 to $3.0 \%$ $\mathrm{N}$ (dry weight) (Fig. 4B), whereas tissue phosphorus ranged from 0.11 to $0.16 \% \mathrm{P}$ (dry weight) (Fig. 4C). Tissue carbon ranged from 25 to $35 \% \mathrm{C}$ (dry weight) (Fig. 4A). The atomic C : N ratio in the tissue of Ulva was from 13 to 19 (Fig. 5A). The atomic $\mathrm{N}: \mathrm{P}$ ratio ranged from 31 to 52 and decreased with increasing salinity levels (Fig. 5C). The atomic C : P ratio was 439 up to 1024 (Fig. 5B). The pattern of internal nutrient content was similar to the growth rate, changing according to salinity, while the atomic ratio decreased with increasing salinity. This trend is unusual, suggesting that salinity levels limit nutrient uptake. These results show that salinity affects phosphate uptake more than nitrate uptake with nutrient limited samples of Ulva.

ANOVA results on the effect of salinity on internal nutrient content are given in Table 2. Tissue $\mathrm{C}, \mathrm{N}$ and $\mathrm{P}$ contents were all significantly different $(\mathrm{p}<0.05, \mathrm{p}<$ 0.001 and $\mathrm{p}<0.01$, respectively). A Tukey's multiple range test of carbon and nitrogen content means showed that carbon content at 40 psu was significantly lower than those at 5, 15, 25 and 34 psu (Tukey tests, p < 0.05) (Fig. $4 \mathrm{~A})$, and nitrogen content at 40 psu was significantly lower than those at 5, 15, 20, 25 and 34 psu (Tukey tests, $\mathrm{p}<0.05$ ) (Fig. 4B). Tissue phosphorus contents at 20 and 34 psu were significantly higher than those at 5 psu (Tukey tests, p < 0.05) (Fig. 4C). Based on multiple comparisons among the levels of salinity, the $\mathrm{C}: \mathrm{N}$ ratios 
at 20, 25 and 34 psu were significantly lower than those at 40 psu (Tukey tests, p < 0.05) (Fig. 5A), whereas C : P ratios at $5 \mathrm{psu}$ were significantly higher than those at 40 psu (Tukey tests, $\mathrm{p}<0.01$ ) (Fig. 5B). The $\mathrm{N}: \mathrm{P}$ ratios at 20
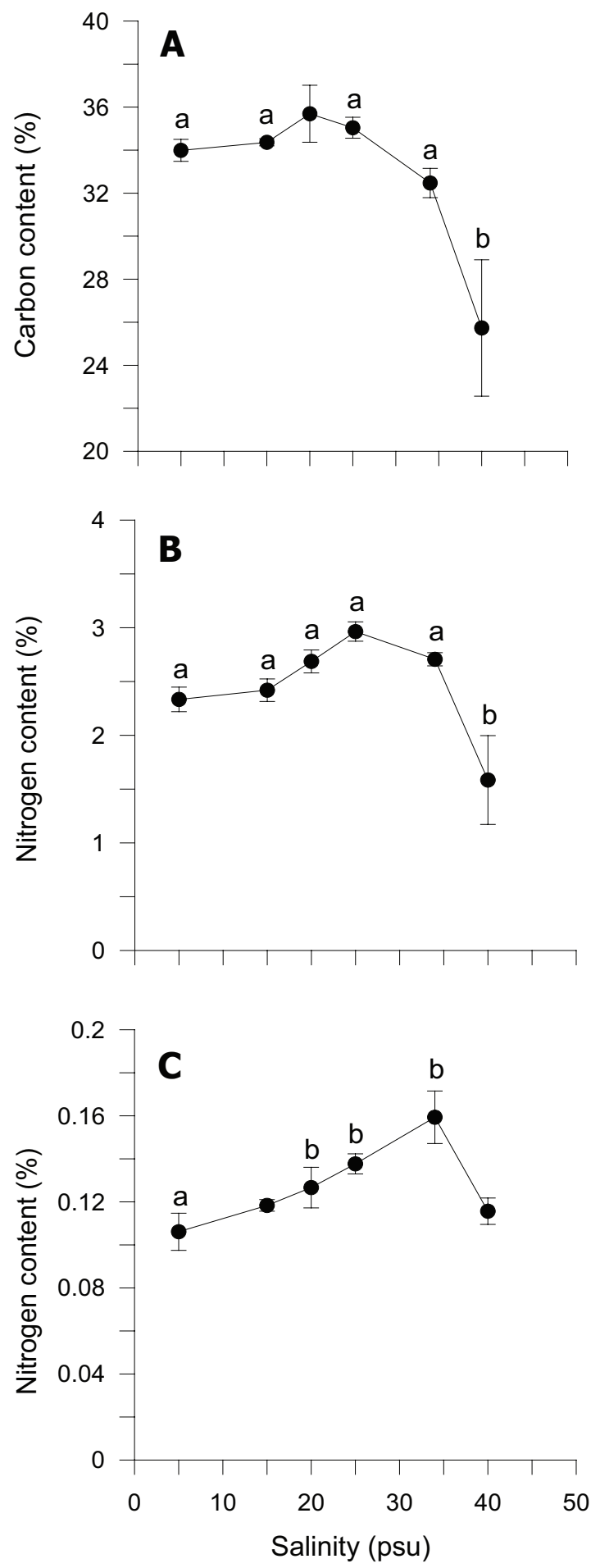

Fig. 4. Carbon (\%) (A), nitrogen (\%) (B) and phosphorus (\%) (C) content in the tissue of Ulva pertusa as a function of salinity. Error bars represent the mean $( \pm S D)$ of 3 replicates. Letters represent the results of multiple comparison test $(p<0.05)$. and 25 psu were significantly lower than those at 5 psu (Tukey tests, $\mathrm{p}<0.05$ ), and significantly higher than that at 40 psu (Tukey tests, p < 0.05) (Fig. 5C).
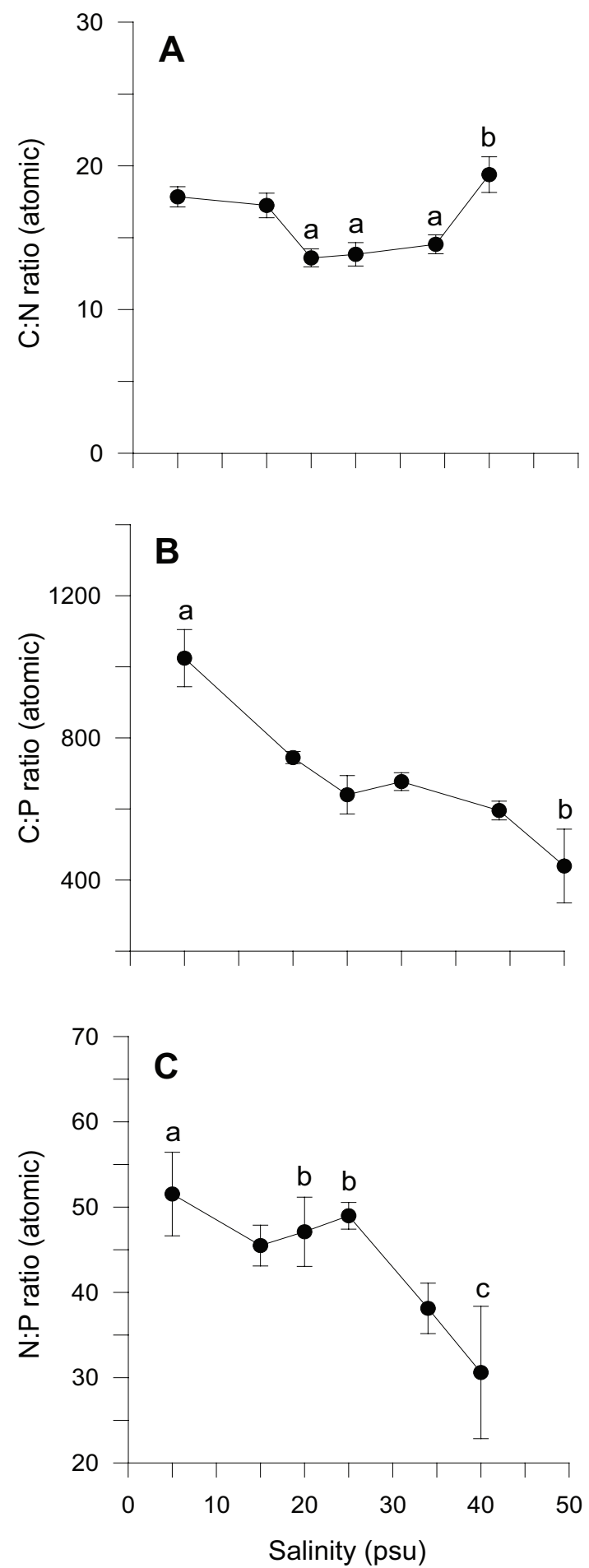

Fig. 5. $\mathrm{C}: \mathrm{N}$ ratio (by atom) (A), $\mathrm{C}: \mathrm{P}$ ratio (by atom) (B) and $\mathrm{N}: \mathrm{P}$ ratio (by atom) (C) in the tissue of Ulva pertusa as a function of salinity. Error bars represent the mean $( \pm S E)$ of 3 replicates. Letters represent the results of multiple comparison test $(p<0.05)$. 


\section{DISCUSSION}

\section{Growth rate and nutrient uptake}

The results of these experiments suggest that under non-limiting nutrient and light conditions within a salinity range from 5 to $40 \mathrm{psu}$, that Ulva shows higher growth rates within the salinity range of 15 to $25 \mathrm{psu}$, with an optimum between 15 and 20 psu. Growth was decreased by low salinity and also at salinities greater than 25 psu (Fig. 1). These results may reflect low tolerance of this species to extremely reduced or raised salinity. Both higher and lower optimal salinities have been reported for various Ulva species (e.g., 25 psu for U. fasciata; Morand and Briand 1996 and U. pertusa; Floreto et al. 1994, and 35-40 psu for U. rigida; Zavodnik 1975). Also, the enhancement of growth rates at lowered salinity (17-22 psu) on Enteromorpha species has previously been reported (Martins et al. 1999). Increased growth rate at reduced salinity has also been reported for marine microalgae (Craggs et al. 1994) and some brown algae (Gordillo et al. 2002). However, reduced salinity often inhibited the growth of marine macroalgae by limiting branching (Norton et al. 1981). Also, growth of marine macroalgae is usually reduced in hypersaline water, because of both cumulative enzyme effects, and reduced turgor pressure, which inhibit cell division (Lee and Liu 1999).

Ulva species have been dominant in some estuaries throughout the year, suggesting that those species may be euryhaline. Some studies suggest that other green macroalgae, e.g., Enteromorpha, are more tolerant of reduced or elevated salinity than Ulva (Martins et al. 1999). In contrast, U. lactuca in culture was more tolerant of hyper-than hyposalinity (Murthy et al. 1988). $U$. rotundata in the field has been growing in salinities ranging from 26 to36 psu (De Casabianca 1989), and $U$. rigida bloomed in summer when salinity remained above 20 psu (Fillit 1995). The effect of salinity on Ulva and Enteromorpha remains controversial. However, our results show that salinity is more important than other environmental factors on the initiation of Ulva bloom in eelgrass beds, especially in the rainy season (late springearly summer).

When exposed to changes in salinity, most intertidal algae appear to utilize a complex set of physiological and biochemical mechanisms in order to acclimatize to fluctuating salinities in their habitat (Lobban and Harrison 1994). It is known that maintenance of constant cell turgor by changing osmotic potential is a typical tolerance mechanism in marine algae exposed to salinity changes (Kirst 1990). The adjustment of osmotic potential can be achieved by changes in the concentration of internal inorganic ions and organic osmolytes (Liu et al. 2000). It is known that proline accumulates in microalgae in response to stresses such as salinity (Lee and Liu 1999).

In our experiment, nitrate and phosphate uptake of Ulva were greater in intermediate levels of salinity (20 and 25 psu) (Fig. 2). These results correspond with growth rate and indicate that Ulva species growing in eelgrass beds are well acclimated to lower salinities. Macroalgae may occasionally respond to a temporal imbalance between growth and nutrient uptake during subsequent periods of low external nutrient supply (McGlathery et al. 1996). In a steady state, the removal of nutrients from ambient water would correspond to the incorporation into new algal biomass. Such uncoupling of growth and nutrient uptake has been demonstrated for several species of macroalgae on seasonal and diurnal time scales (Rosenberg and Ramus 1982, Trimmer et al. 2000). Uptake rates for phosphate increased more rapidly than for nitrate at lowered salinities range from 5 to 20 psu (Fig. 2). This in turn corresponded to a decreased N : P ratio with higher salinities (Fig. 5C). Thus, the effect of salinity on nitrate uptake was stronger than on phosphate uptake, especially at lower salinities. Gordillo et al. (2002) pointed out that nitrate uptake for brown algae was more reduced than phosphate uptake at low salinities. The $\mathrm{N}: \mathrm{P}$ ratio for uptake rates ranged from 12.4 (25 psu) to 37.7 (5 psu) (data not shown). Accordingly, a higher utilization of internal nitrogen than of internal phosphorus reserves to synthesize organic components by the Ulva could be responsible for the lower $\mathrm{N}$ : $\mathrm{P}$ ratio for internal tissue contents than for uptake rates (Fig. 5C).

\section{Photosynthetic performance}

Adaptation of Ulva to a wide-range of salinity regimes is important in an intertidal and estuarine environment characterized by periodic exposure to air by tide and inflow of freshwater (Kamer and Fong 2000). Both a decrease and increase of salinity resulted in reduced algal productivity and biomass. It coincided with a decreased chlorophyll- $a$ content and effective quantum yield (Fig. 3). Reductions in photosynthetic rate are indicative of some stress to the photosynthetic system or other factor involved in the photosynthetic process. Chlorosis occurred during the experiment at both high $(\geq 34 \mathrm{psu})$ and low salinity levels ( $\leq 5 \mathrm{psu}$ ), indicated by thylakoid destruction (Liu et al. 2000). Reduced chlorophyll- $a$ content might be one factor causing the reduction in photosynthetic rate.

Similar responses were shown between growth rate 
and effective quantum yield as a function of salinity treatment (Figs 1 \& 3B). Depression or inhibition of algal photosynthesis occurred under low- and high-salinity levels, which may be related to the degree of tolerance or adaptation to salinity. Several studies have found a sharp drop in photosynthetic rate for several marine macroalgae including U. lactuca at lower salinities , and this has been linked to an effect of carbon supply $\left(\mathrm{CO}_{2}\right.$ and $\mathrm{HCO}_{3}$ ) (Rivers and Peckol 1995). The reduction of photosynthesis may have been due partly to inhibition of individual enzymes, such as RuBisCO, but it also could be due to structural/mechanical effects (Lobban and Harrison 1994).

\section{Internal tissue nutrients}

The carbon, nitrogen and phosphorus content of algal tissue is related to ambient nutrient conditions and uptake prior to sample collection, and likely provide a more reliable indication of nutrient status (Wheeler and Björnsäter 1992, Gordillo et al. 2002). Also, the primary element content of Ulva was affected by salinity. In the seagrass bed, nutrients previously bound to macrophytes become available for phytoplankton and opportunistic macroalgal growth (Sfriso and Marcomini 1997). The consequence of this nutrient flux is a structural change in the ecosystem, from a grazer controlled system to a detritus/mineralization system, where the turnover of oxygen and nutrients is much more dynamic (Lavery et al. 1991). Frequently, the occurrence of such collapses also contributes to a decrease in the biodiversity of the area (Everett 1994).

In our study, carbon and nitrogen content of Ulva was not significantly different from 5 to $34 \mathrm{psu}$, but significantly decreased at 40 psu (Figs $4 A$ \& B). However, phosphorus content was significantly higher at 20, 25 and 34 psu than at 5 psu (Fig. 4C). Usually, nitrogen content in the tissue of macroalgae is related to chlorophyll- $a$ content. However, our results did not show a close correlation between nitrogen content and chlorophyll- $a$ content $\left(r^{2}=0.4936\right)$. Chlorophyll-bound $\mathrm{N}$ typically changes in response to macroalgal $\mathrm{N}$ status, but because this pool represents $<2 \%$ of total thallus $\mathrm{N}$, it does not contribute significantly to $\mathrm{N}$ storage (McGlathery et al. 1996).

A C : N ratio of 7-15:1 has been reported for $U$. lactuca in a fishpond, and 9-16:1 for $U$. rigida in the field (Rivers and Peckol 1995). Our range, 13-19: 1 for $\mathrm{C}: \mathrm{N}$ ratio was higher than those ratios (Fig. 5A), however this may be because this was a laboratory culture experiment. Fong et al. (1996) suggested that differential salinity tolerances and $\mathrm{N}$ requirements might determine the pattern of succession for dominant macroalgae in coastal lagoons of southern California. As such, salinity tolerance and adaptation in macroalgae is more important than other environmental variables. High nitrogen and phosphorus availability resulted in high tissue $\mathrm{N}$ and $\mathrm{P}$, and in intermediate tissue $\mathrm{N}$ : $\mathrm{P}$ ratio. Conversely, high nitrogen and low phosphorus availability resulted in high tissue $\mathrm{N}$, low tissue $\mathrm{P}$, and high tissue N : P ratio (Wheeler and Björnsäter 1992). Thus, nitrogen limitation was indicated by low tissue nitrogen content and low tissue N : P. Phosphorus limitation was indicated by low tissue phosphorus and high tissue N : P (Wheeler and Björnsäter 1992). The N : $P$ ratio 31-53 in our experiment seemed to be the result of preferential uptake for nitrogen over phosphorus (Fig. $5 \mathrm{C})$.

It can be concluded that green macroalgae such as Ulva and Enteromorpha have a broader salinity tolerance than strictly marine algae; additionally, within a marine environment, intertidal species can better tolerate low salinities than sublittoral species (Lobban and Harrison 1994, Kamer and Fong 2000). In seagrass beds, however, salinity has been considered less important than other environmental factors such as light and temperature on the ecology of green macroalgae. There are numerous unanswered fundamental questions about the effect of salinity on green-tide causing macroalgae, providing opportunities for research ranging from field ecology to molecular biology and biochemistry. Field experiments are essential to determine the impact of single and multiple stresses on the ecophysiological dynamics of macroalgal populations. Thus, both field and laboratory studies are necessary to gain insight into seagrass decline by green macroalgal blooms in eutrophic areas.

\section{ACKNOWLEDGEMENTS}

We thank In Ji Song and Seo Young Kang for field survey and technical support. This paper was funded by a grant from the Ministry of Land, Transport and Maritime Affairs (Republic of Korea).

\section{REFERENCES}

Burkholder, J. M., Tomasko, D. A. \& Touchette, B. W. 2007. Seagrasses and eutrophication. J. Exp. Mar. Biol. Ecol. 350:46-72.

Choi, T. S., Kim, J. H. \& Kim, K. Y. 2001. Seasonal changes in the abundance of Ulva mats on a rocky intertidal zone of the southern coast of Korea. Algae 16:337341 . 
Craggs, R. J., McAuley, P. J. \& Smith, V. J. 1994. Batch culture screening of marine microalgal nutrient removal from primary sewage effluent. Hydrobiologia 288:157-166.

Davison, I. R. \& Pearson, G. A. 1996. Stress tolerance in intertidal seaweeds. J. Phycol. 32:197-211.

De Casabianca, M. L. 1989. Degradation of Ulva (Ulva rotundata, Prévost Lagoon, France). C. R. Acad. Sci. Paris 308:155-160

D’Elia, C. F., Steudler, P. A. \& Corwin, N. 1977. Determination of total nitrogen in aqueous samples using persulphate digestion. Limnol. Oceanogr. 22:760-764.

Dickson, D. M. J., Wyn-Jones, R. G. \& Davenport, J. 1982. Osmotic adaptation in Ulva latuca under fluctuating salinity regimes. Planta 155:409-415.

Edward, D. M., Reed, R. H., Chudek, J. A., Foster, R. \& Stewart, W. D. P. 1987. Organic solute accumulation in osmotically-stressed Enteromorpha intestinalis. Mar. Biol. 95:583-592.

Everett, R. A. 1994. Macroalgae in marine soft-sediment communities: effects on benthic faunal assemblages.

J. Exp. Mar. Biol. Ecol. 175:253-274.

Fillit, M. 1995. Seasonal changes in the photosynthetic capacities and pigment content of Ulva rigida in a Mediterranean coastal lagoon. Bot. Mar. 38:271-280.

Floreto, E. A. T., Hirata, H., Yamasaki, S. \& Castro, S. C. 1994. Effect of salinity on the growth and fatty acid composition of Ulva pertusa Kjellman (Chlorophyta). Bot. Mar. 37:151-155

Fong, P., Boyer, K. E., Desmond, J. S. \& Zedler, J. B. 1996. Salinity stress, nitrogen competition, and facilitation: what controls seasonal succession of two opportunistic green macroalgae? J. Exp. Mar. Biol. Ecol. 206:203-221.

Gordillo, F. J. L., Dring, M. J. \& Savidge, G. 2002. Nitrate and phosphate uptake characteristics of three species of brown algae cultured at low salinity. Mar. Ecol. Prog. Ser. 234:111-118.

Grasshoff, K., Ehrhardt, M. \& Kremling, K. 1983. Methods of seawater analysis. Verlag Chemie, Weinheim, 419 pp.

Hauxwell, J., Cebrian, J., Furlong, C. \& Valiela, I. 2001. Macroalgal canopies contribute to eelgrass (Zostera marina) decline in temperate estuarine ecosystems. Ecology 82:1007-1022.

Hemminga, M. A. \& Duarte, C. M. 2000. Seagrass ecology. Cambridge University Press, Cambridge, 298 pp.

Hull, S. C. 1987. Macroalgal mats and species abundance: a field experiment. Estuar. Coast. Shelf Sci. 25:519-532.

Isaksson, I. \& Phil, L. 1992. Structural changes in benthic macrovegetation and associated epibenthic faunal communities. Neth. J. Sea Res. 30:131-140.

Jeffrey, S. W. \& Humphrey, G. F. 1975. New spectrophotometric equations for determining chlorophylls a, b, c1and c2 in higher plants, algae and natural phytoplankton. Biochem. Physiol. Pflanzen 167:191194.

Kamer, K. \& Fong, P. 2000. A fluctuating salinity regime mitigates the negative effects of reduced salinity on the estuarine macroalga, Enteromorpha intestinalis (L.) link. J. Exp. Mar. Biol. Ecol. 254:53-69.

Kim, K. Y., Choi, T. S., Kim, J. H., Han, T., Shin, H. W. \& Garbary, D. J. 2004. Physiological ecology and seasonality of Ulva pertusa on a temperate rocky shore. Phycologia 43:483-492.

Kinney, E. H. \& Roman, C. T. 1998. Response of primary producers to nutrient enrichment in a shallow estuary. Mar. Ecol. Prog. Ser.163:89-98.

Kirst, G. O. 1990. Salinity tolerance of eukaryotic marine algae. Annu. Rev. Plant Physiol. Plant Mol. Biol. 41:21-53.

Krause-Jensen, D., Middelboe, A. L., Sand-Jensen, K. \& Christensen, P. B. 2000. Eelgrass, Zostera marina, growth along depth gradients: upper boundaries of the variation as a powerful predictive tool. Oikos 91:233-244.

Lavery, P. S., Lukatelich, R. J. \& McComb, A. J. 1991. Changes in the biomass and species composition of macroalgae in a eutrophic estuary. Estuar. Coast. Shelf Sci. 33:1-22.

Lee, T. M. \& Liu, C. H. 1999. Correlation of decreased calcium contents with proline accumulation in the marine green macroalga Ulva fasciata exposed to elevated $\mathrm{NaCl}$ contents in seawater. J. Exp. Bot. 50:1855-1862.

Liu, C. H., Shih, M. C. \& Lee, T. M. 2000. Free proline levels in Ulva (Chlorophyta) in response to hypersalinity: elevated $\mathrm{NaCl}$ in seawater versus concentrated seawater. J. Phycol. 36:118-119.

Liu, D. Y., Keesing, J. K., Xing, Q. G. \& Shi, P. 2009. World's largest macroalgal bloom caused by expansion of seaweed aquaculture in China. Mar. Pollut. Bull. 58:888-895.

Lobban, C. S. \& Harrison, P. J. 1994. Seaweed ecology and physiology. Cambridge University Press, Cambridge, $366 \mathrm{pp}$.

Martins, I., Oliveira, S. M., Flindt, M. R. \& Marques, J. C. 1999. The effect of salinity on the growth rate of the macroalgae Enteromorpha intestinalis (Chlorophyta) in the Mondego estuary (west Portugal). Acta Oecol. 20:259-265.

Martins, I., Pardal, M. A., Lillebø, A. I., Flindt, M. R. \& 
Marques, J. C. 2001. Hydrodynamics as a major factor controlling the occurrence of green macroalgal blooms in a eutrophic estuary: a case study on the influence of precipitation and river management. Est. Coast. Shelf Sci. 52:165-177.

McGlathery, K. J. 2001. Macroalgal blooms contribute to the decline of seagrass in nutrient-enriched coastal waters. J. Phycol. 37:453-456.

McGlathery, K. J., Pedersen, M. F. \& Borum, J. 1996. Changes in intracellular nitrogen pools and feedback controls on nitrogen uptake in Chaetomorpha linum (Chlorophyta). J. Phycol. 32:393-401.

Morand, P. \& Briand, X. 1996. Excessive growth of macroalgae: a symptom of environmental disturbance. Bot. Mar. 39:491-516.

Murthy, M. S., Sharma, C. L. N. S. \& Rao, Y. N. 1988. Salinity induced changes in peroxidase activity in the green seaweed Ulva lactuca. Bot. Mar. 31:307310.

Nedergaard, R. I., Risgaard-Petersen N. \& Finster, K. 2002. The importance of sulfate reduction associated with Ulva lactuca thalli during decomposition: a mesocosm experiment. J. Exp. Mar. Biol. Ecol. 275:15-29.

Nelson, T. A., Haberlin, K., Nelson, A. V., Ribarich, H., Hotchkiss, R., Van Alstyne, K. L., Buckingham, L., Simunds, D. J. \& Fredrickson, K. 2008. Ecological and physiological controls of species composition in green macroalgal blooms. Ecology 89:1287-1298.

Norton, T. A., Mathieson, A. C. \& Neushul, M. 1981. Morphology and envirionment. In Lobban, C. S. \& Wynne, M. J. (Eds.) The Biology of Seaweeds. Blackwell Scientific, Oxford, pp. 421-451.

Ritchie, R. J. \& Larkum, A. W. D. 1987. The ionic relations of small-celled marine algae. Prog. Phycol. Res. 5:179-222.

Rivers, J. S. \& Peckol, P. 1995. Interactive effects of nitrogen and dissolved inorganic carbon on photosynthesis, growth, and ammonium uptake of macroalgae, Cladophora vagabunda and Gracilaria tikvahiae. Mar. Biol. 121:747-753.

Rosenberg, G. \& Ramus, J. 1982. Ecological growth strategies in the seaweeds Gracilaria folifera (Rhodophyceae) and Ulva sp. (Chlorophyceae): soluble nitrogen and reserve carbohydrates. Mar. Biol. 66:251-259.

Schramm, W. 1996. The Baltic sea and its transition zones. In Schramm, W. \& Nienhuis, P. H. Marine Benthic Vegetation: Recent Changes and the Effects of Eutrophication. Springer-Verlag, Berlin, pp. 133.

Schreiber, U. \& Bilger, W. 1993. Progress in chlorophyll fluorescence research: major developments during the past years in retrospect. Prog. Bot. 54:151-173.

Sfriso, A. \& Marcomini, A. 1997. Macrophyte production in a shallow coastal lagoon: 1. Coupling with chemico-physical parameters and nutrient concentrations in waters. Mar. Environ. Res. 44:351375.

Sfriso, A., Pavoni, B., Marcomini, A. \& Orio, A. A. 1992. Macroalgae, nutrient cycles, and pollutants in the lagoon of Venice. Estuaries 15:517-528.

Short, F. T., Burdick, D. M. \& Kaldy, J. E. 1995. Mesocosm experiments quantify the effects of eutrophication on eelgrass, Zostera marina. Limnol. Oceanogr. 40:740-749.

Trimmer, M., Nedwell, D. B., Sivyer, D. B. \& Malcolm, S. J. 2000. Seasonal organic mineralisation and denitrification in intertidal sediments and their relationship to the abundance of Enteromorpha sp. and Ulva sp. Mar. Ecol. Prog. Ser. 203:67-80.

Valiela, I., McClelland, J., Hauxwell, J., Behr, P. J., Hersh, D. \& Foreman, K. 1997. Macroalgal blooms in shallow estuaries: controls and ecophysiological and ecosystem consequences. Limnol. Oceanogr. 42:1105-1118.

Wheeler, P. A. \& Björnsäter, B. R. 1992. Seasonal fluctuations in tissue nitrogen, phosphorus, and N-P for five macroalgal species common to the Pacific northwest coast. J. Phycol. 28:1-6.

Yarish, C. \& Edwards, P. 1982. A field and cultural investigation of the horizontal and seasonal distribution of estuarine red algae of New Jersey. Phycologia 21:112-124.

Young, A. J., Collins, J. C. \& Russell, G. 1987a. Solute regulation in the euryhaline marine alga Enteromorpha prolifera (O. F. Müll.). J. Ag. J. Exp. Bot. 38:1298-1308.

Young, A. J., Collins, J. C. \& Russell, G. 1987b. Ecotypic variation in the osmotic responses of Enteromorpha intestinalis (L.) Link. J. Exp. Bot. 38:1309-1324.

Zavodnik, N. 1975. Effects of temperature and salinity variations on photosynthesis of some littoral seaweeds of the North Adriatic Sea. Bot. Mar. 18:245250 . 